\title{
Radiocarbon
}

\author{
1984
}

\section{ZERO BP PLUS 34: 25 YEARS OF RADIOCARBON}

EDWARD S DEEVEY, JR

Florida State Museum, University of Florida, Gainesville 32611

Very incautiously, after printing 25 volumes of Radiocarbon, the editors have authorized some personal reminiscence. Like all "Quaternary scientists" - no better collective name is available for our strange profession-I have been engaged in historiography, writing about history, for many years. In 1946, when natural radiocarbon was discovered, my subject, the sedimentary history of lakes, was only one of several kinds of historical record that needed, and soon received, a new reading. At the time, not all custodians of other kinds of record were ready to agree that new readings were conceivable, let alone necessary. The record of their persuasion-some of which has been written by Greg Marlowe (1980) in "W F Libby and the Archaeologists"-is part of the history of historiography. To the bibliography of this dangerously abstract subject I venture to add some minor footnotes. They come, not from historical research like Marlowe's, but from a leaky, selective memory.

Radiocarbon was founded 25 years ago, as the Radiocarbon Supplement of the American Journal of Science. The editors of the parent journal, founded in 1818 by Benjamin Silliman, are also its publishers. I take this opportunity to scotch the rumor that AJS was a house organ of the Yale Department of Geology. The fact is that several members of other Yale departments, including Biology (then Zoology) and Chemistry, were also members of the board. As an independent proprietary journal, beholden to no professional organization or firm, AJS had the authority to publish anything in earth science that it could afford. Once launched, the Supplement was aided in becoming a separate journal by a grant, GN 396, from the National Science Foundation, under a publicationsassistance program that was dissolved shortly thereafter. When the AJS board received our proposal, which had been prompted by encouraging memos from Hilde Levi, chairman of an international association of working laboratories, it acted with vision, and with sufficient dispatch to forestall a competing proposal from another journal. It is not fair to say that the board had no choice, for the founding editors-Richard Foster Flint, G Evelyn Hutchinson, and I-could easily have been outvoted. My recollection that Flint saw to it that we were not is not wholly wrong, but the record shows that Hutchinson chaired the crucial meeting on November $21,1957$.

So much for the facts; readers of Radiocarbon will surely be more interested in the background. The background of ${ }^{14} \mathrm{C}$ measurements con- 
sists mainly of cosmic radiation, and is sternly suppressed by anti-coincidence devices under several inches of lead. Having now, contrary to my instincts and training, to de-suppress it, I am conscious that my training was uninfluenced by radiation of any sort. In fact, my shallow experience with analytical chemistry was slender preparation for the turn in my career that began in the zero year, AD 1950. Before attempting to grapple with Willard Libby's discovery and its early sequelae, I should mention some later events, less physical than political, in the background of $R a$ diocarbon.

Although Libby's discovery was announced in Physical Review (Libby, 1946), nearly all the early papers, from Chicago and from all other laboratories, were published in Science. The procession began with the confirmation of Grosse's 1934 prediction (Grosse \& Libby, 1947) and included the first measurements from Chicago and numerous others (Libby, Anderson, \& Arnold, 1949; Arnold \& Libby, 1949, 1951; Kulp, Feely, \& Tryon, 1951; Blau, Deevey, \& Gross, 1954; Suess, 1954). Chicago V (Libby, 1954), the last date list from Chicago, was published as a dozen or more laboratories were tooling up. By 1957, as their output proliferated beyond his endurance, the editor of Science, Graham DuShane, foresaw a takeover. His letter accepting Yale III complained, with some justice, that Science was not an "archive" for any branch of science.

In responding to DuShane's challenge, though, Flint, Hutchinson, and I were less concerned with creating an archive than with insuring editorial control over original publication of measurements. By 1957 many dates, including some that were certainly wrong, were being widely quoted by journalists and others. Not only did the numbers lack precision or attribution; many contained "corrections," often expressing nothing but historians' misunderstanding of that unfamiliar, insulting, and badly named concept, "standard error." Besides, by 1957, new estimates of the half-life of ${ }^{14} \mathrm{C}$ threatened utter chaos in the literature. Flint's tidy mind rebelled at the prospect that every published repetition of a measurement would inflate its age by three per cent per citation. Value is sometimes created by that route in economics; suppose the next editor of Science were to be an economist?

The cosmic background of Libby's discovery, then, was forecast by A V Grosse in 1934, the year in which Harold Urey won his Nobel prize. Carbon-14 was identified by Ruben and Kamen in 1940. Libby's great contribution, appropriately shared with Grosse in 1947, was to detect and measure the isotope "in nature"-an elastic concept stretched to embrace sewer gas from the city of Baltimore. This curious choice was dictated by the fact that methane, a gas, could be isotopically enriched by thermal diffusion, a technique with which graduates of the Manhattan District had some experience. Just when Libby hit on the notion of "modern wood," and selected some 20 pieces big enough (and therefore old enough) to mask the Suess (industrial carbon) effect, I do not know ${ }^{1}$. When I

${ }^{1}$ Libby's legendary luck, which brought the Nobel award in 1960, was only incidentally displayed by the choice of modern tree-rings that were formed before much fossil carbon had been added to the atmosphere. The modern-wood assay, later revised 
visited Chicago's Institute for Nuclear Studies in 1949, Ernest Anderson's thesis had been defended and Anderson was chasing neutrinos; James Arnold was talking about meteorites; my pollen-dated peat samples from Connecticut and elsewhere were being processed; and the three-story diffusion column stood idle in a stairwell.

Yale's Geochronometric Laboratory was established in 1951, with the aid of a grant from The Rockefeller Foundation. The background I know about began there, at 77 Prospect Street, in the basement of a disused fraternity house where some mysterious emanations were first attributed (by Hans Suess) to residual Potassium- $40^{2}$ on the bar-room floor. Several coats of strippable paint failed to abolish this prototypic Suess effect. By 1954, when atmospheric weapons-testing was declassified, we knew that we had been measuring Carbon-14 all along. Unfortunately the accuracy depended on the time of exposure of the Libby slurry (solid carbon in water with $0.5 \%$ of egg albumen ${ }^{3}$ ) to the enriched New Haven atmosphere. Abandoning solid carbon and screen-wall counters to history's scrap-heap, we converted first to acetylene (holding it long enough to be scooped by several laboratories on the total synthesis of benzene from the sample gas) and then to gaseous carbon dioxide. This de Vriesian substance we imported from Groningen, along with G W Barendsen, who replaced Monte Blau as our premier geochronometer. Barendsen's novel, and prophetic, contribution was to prove the feasibility of scintillationcounting of ${ }^{14} \mathrm{C}$. But liquid carbon dioxide was a weak source of beta-rays, even under 15 atmospheres' pressure, and Minze Stuiver returned the lab to de Vries' original procedure. Soon thereafter-we are now up to 1963 in this condensed review - the re-named Radiocarbon Laboratory moved to the Kline Geology Laboratory ("Flint's Fort"), with Stuiver as Senior Research Associate and Director.

Going back to 1951, the Rockefeller Foundation grant that made all this possible was not negotiated by a non-tenured assistant professor of biology. Yale owes it to the prescience of two remarkable administrators.

upward for counting efficiencies, was $12.5 \mathrm{dpm}$ per gram (Libby, Anderson, \& Arnold, 1949). Three sea-shell measurements, best interpreted as "probably contaminated," gave values ranging from 6.4 to $19.2 \%$ above the terrestrial assay. Libby ignored all three, choosing for the marine biosphere the theoretical value of 1.05 times modern wood, obtained by doubling the ${ }^{13} \mathrm{C}$ difference between wood and shell. Agreement of the specific activity of the biosphere with that calculated from the cosmic-ray neutron flux was therefore due, as Libby suggested (1952, p 29), "in some part to cancellation of crrors." Projecting the modern-wood assay backward in time, and using a half-life, $5720 \pm 47$ years, which was not accepted until several years later, Arnold and Libby (1949) successfully dated several wood samples from ancient Egypt. Had they used the shorter, 5568-year half-life, Sneferu's tomb (C-12; Chicago I) would have appeared "too young" by 240 years - unless the sample count was referred to a higher modern assay, as it was in Chicago I, where it is 227 years "too old." But among the errors that kept the results "within statistics" (give or take half a millennium) was a bigger one, the third-millennium BC enrichment of the biosphere's radiocarbon by 3 to $9 \%$. From his tomb, the Pharoah evidently conspired with Libby to select the smaller figure, thercby predicting both his true age and (within ten years of 5730 ) the correct half-life of ${ }^{11} \mathrm{C}$.

Editor's Note: Evidently radon-this is a decay product in the uranium series and cannot be from ${ }^{40} \mathrm{~K}$. MS

${ }^{3}$ The ingredient reminds one of Libby's assurance, given orally to Hutchinson, that the new technology was "about as difficult as an appendectomy, or baking a really good cake." 
A Whitney Griswold is the only university president, as W C DeVane is the only college dean, for whom an assistant professor-this one at any rate-could ever substitute unreserved admiration for native, faculty-type skepticism. Once established, though, if the Laboratory were not to be a new department or research institute-units for which that dean and that president had reciprocal, well-grounded distaste-its policies and operations needed the guidance of a faculty committee. Libby's dating project had been guided by a joint committee of the American Anthropological Association and the Geological Society of America (Johnson, 1951). Yale's counterpart was an interdepartmental Advisory Board, which began to hold monthly meetings in 1951.

On this Board Flint, the chairman, represented Geology and the G S A committee; Hutchinson, vice chairman, was officially in Zoology. Other members of the Board, to which I as Director was responsible, were Wendell Bennett (Anthropology), George Kubler (History of Art), C G Montgomery (Physics), and Henry Thomas (Chemistry). On their deaths, at shatteringly early ages, Bennett was replaced by Irving Rouse and Montgomery's place was taken by Henry Kraybill. When organized for educational purposes, such diversified faculty groups are commonplace, but ours was a research project. Rarely, I think, has so complex a project been conducted by a committee with so much collegiality and profound, if irreverent, scholarship.

What this research was about was clear to the Board, but difficult to describe to others. Only incidentally, in its early years, was it concerned with dating samples of interest to geology, archaeology, or (preferably) both, such as were left by the Upper Paleolithic cultures of the late Pleistocene. Before dating could be routine, we faced a clutch of "methodological problems," nearly all of which turned out to be facets of the same problem, the specific radioactivity of "modern" carbon. In a word, the problem was biogeochemical, but "bio-", "geo-", and "-chemical" stood for separate cultural traditions, not yet known to be united by historiography. Sometimes, as in the case of lake marl surrouncling certain Magdalenian artifacts near Hamburg, the problem was exposed by discordant dates based on different materials. Just as often, it was exposed by pure ratiocination, otherwise known as "borrowing trouble"-the kind of trouble that arises when the errors fail to cancel.

The chief ratiocinator in all this was Hutchinson, whose knowledge of the biosphere's chemical history was unrivaled. I pause here to note that from here (1951) onward I am writing of a large and increasingly visible corps of Quaternary scientists, for whom Radiocarbon became a journal of record in 1959. Most of the practicing biogeochemists among them came together at three international conferences, at Copenhagen in 1954, at Andover in 1955, and at Cambridge in 1957. Before 1950, however, there was a smaller group, a true "invisible college," about which I know nothing at first hand. Described as a "floating seminar on cosmochemistry," it seems to have met whenever and wherever Hutchinson and Urey happened to attend the same scientific meeting. Among its other 
American members were William Rubey and Lloyd Berkner. From conversations with Hilde Levi, I know that her professor, Niels Bohr-a biologist before he turned to physics-was at least an occasional participant. From a meeting of this group, probably at the National Academy of Sciences in 1946 or 1947, Hutchinson brought word of what promised to be, and was, the most productive discovery of modern times. But again, I can't say when Libby became a member. Much later, in 1957, he told me that his own invisible college was founded at Berkeley by G N Lewis.

So our problems came to focus on the modern assay, of carbonates in particular. For sea-shells, we could confirm neither Libby's theoretical value, 1.05 times modern wood, nor the higher values that probably contained some stray radiation from the Institute for Nuclear Studies. Either the surface ocean was made of upwelled, 400-year-old sea water, or fossil fuels had been added to the ocean since the Neolithic. Kubler and Rouse assured us that very few coal-fired pottery kilns existed outside the Pueblo archaeological area. But if most of the world's industrial carbon has suffered a sea-change, why is there still so much of it in today's atmosphere? And if that increment is not all industrial, as Hutchinson had been arguing, contra Conway, for several years, how much of it could be "truly modern," perhaps evaded to the air from a warmer ocean? Could it be derived from decreased agricultural production, or from the oxidation of humus in soil?

Suess, awaiting the construction of his new laboratory by the $\mathrm{U} S$ Geological Survey, was a vigorous participant in these discussions. Returning to the laboratory after one luncheon meeting of the Board, he and Blau shaved some of the last ten years' growth from our reference standard, a piece of black oak hewn from Flint's woodlot by a willing graduate student. Splitting the green wood with some difficulty, they prepared another sample from the center, laid down about 1900. Unfortunately, after reduction to solid carbon, both samples picked up some of the mysterious emanations from Eniwetok, and the experiment had to be repeated when Suess reached Washington (Suess, 1955). As 1950 wood contained $2 \%$ less radiocarbon than 1890 wood, industrial carbon is indeed present, in amounts that oceanographers and others find worrisome (Broecker, Peng, \& Engh, 1980). Meanwhile, the Board took notice of another quirk of the modern assay, reflecting the predilection of freshwater algae and pondweeds for carbon redissolved, as bicarbonate, from ancient limestone (Deevey et al, 1954). A little later, when Stuiver came from Groningen, bringing a model that implicated sunspots as the source of de Vries' puzzling fluctuations of ${ }^{14} \mathrm{C}$ in older tree-rings, we were ready to believe that physics and chemistry were at last one subject, that biology had captured both, and that geology and history were different names for the field of their interaction.

From Lascaux to the pharoahs and Teotihuacan; from the Glacier Peak eruption to Ilopango and Tambora; from tundra to rain forest, from ground sloths to goats; from neutrons to sunspots, precessions. and magnetic reversals; has any branch of historical science, any sector of 
the atmosphere-hydrosphere-lithosphere-biosphere-cryosphere system remained untouched by some application of Libby's momentous discovery? In 1984, the 34th year since "BP" came to mean "Bill's Practice," it seems unlikely. But when comparable new discoveries are made, we can expect to find an abstract in a future issue of Radiocarbon.

\section{REFERENCFS}

Arnold, J R and Libby, W F, 1949, Age determinations by radiocarbon content: checks with samples of known age: Science, v 110, p 678-680.

1951, Radiocarbon dates: Science, v 113, p 111-120.

, Deevey, E S, and Gralenski, L J, 1957, Yale natural radiocarbon measurements III: Science, v 126, p 908-919.

Blau, Monte, Deevey, E S, and Gross, M S, 1954, Yale natural radiocarbon measurements. I. Pyramid Valley, New Zealand, and its problems: Science, v 118, p 1-6.

Broecker, W S, Peng, T-H, and Engh, R, 1980, Modeling the carbon system, in Stuiver, Minze and Kra, Renee, eds, Internatl radiocarbon conf, 10th, Proc: Radiocarbon,
v 22, no. 3, p 565-598.

Deevey, E S, Gross, M S, Hutchinson, G E, and Kraybill, Henry, 1954, The natural $\mathrm{C}^{14}$ contents of materials from hard-water lakes: Natl Acad Sci, Proc, v 40, p 285-288.

Grosse, A V and Libby, W F, 1947, Cosmic radiocarbon and natural radioactivity of living matter: Science, v 106, p 88-89.

Kulp, J L, Feely, H W, and Tryon, L E, 1951, Lamont natural radiocarbon measurements I: Science, v 114, p 565-568.

Johnson, Frederick, 1951, Radiocarbon dating: Soc Am Archacol Mem, 8, Am Antiquity, v 17, no. 1, pt 2, 65 p. Libby, W F, 1946, Atmospheric helium 3 and radiocarbon from cosmic radiation: Phys
Rev, v 69, p $671-672$.

1952, Radiocarbon dating: Chicago, Univ Chicago Press, 124 p.

1954, Chicago radiocarbon dates V: Science, v 120, p 733-742.

Libby, W F, Anderson, E C, and Arnold, J R, 1949, Age determination by radiocarbon content: world-wide assay of natural radiocarbon: Science, v 109, p 227-228.

Marlowe, Greg, 1980, W F Libby and the archacologists, 1946-1948, in Stuiver, Minze and Kra, Renee, eds, Internatl radiocarbon conf, 10th, Proc: Radiocarbon, v 22,
no. 3, p 1005-1014.

Suess, H E, 1954, US Geological Survey radiocarbon dates I: Science, v 120, p 467-473. 1955, Radiocarbon concentration in modern wood: Science, v 122, p 415-417. 